Archives of Agriculture and Environmental Science

\title{
Appraisal of surface water quality for irrigation collected from Sadar upazila of Jamalpur district, Bangladesh
}

\author{
Arifa Akter, H.M. Zakir * (D) , Atiqur Rahman, Rumana Yesmeen and M.S. Rahman
}

Department of Agricultural Chemistry, Faculty of Agriculture, Bangladesh Agricultural University, Mymensingh-2202, BANGLADESH

"Corresponding author's E-mail: zakirhm.ac.bau@gmail.com

\section{ARTICLE HISTORY}

Received: 14 August 2018

Revised received: 22 August 2018

Accepted: 26 August 2018

\section{Keywords}

Bangladesh

Heavy metal

Irrigation

Jamalpur Sadar

Surface water quality

\begin{abstract}
An attempt was made to assess surface water quality for irrigation collected from Sadar upazila of Jamalpur district, Bangladesh. Total 22 water samples were collected from the study area and analyzed for various physicochemical parameters following standard protocols at the Department of Agricultural Chemistry, Bangladesh Agricultural University, Mymensingh. Major cation and anion chemistry showed their dominance in order of $\mathrm{Ca}>\mathrm{K}>\mathrm{Na}>\mathrm{Mg}$ and $\mathrm{HCO}_{3}>\mathrm{Cl}$ $>\mathrm{SO}_{4}>\mathrm{BO}_{3}>\mathrm{PO}_{4}>\mathrm{CO}_{3}$, respectively. The study revealed that 18,14 and 6 samples were unsuitable for irrigation in respect of $\mathrm{HCO}_{3}, \mathrm{~K}$ and $\mathrm{BO}_{3}$ contents in water, respectively. Among the heavy metals, the concentration of $\mathrm{Pb}, \mathrm{Mn}, \mathrm{Cd}$ and $\mathrm{Cu}$ in water were comparatively higher than the standard limits, which makes 22, 14, 10 and 3 samples problematic for long term irrigation in the study area. Electrical conductivity (EC) and sodium adsorption ratio (SAR) reflected that surface water samples were low to very high salinity (C1-C4) and low alkalinity (S1) hazards classes. As regards to hardness, out of 22 water samples, 2 were very hard, 8 were hard, 11 were moderately hard and only one was soft in quality. The study results concluded that $\mathrm{HCO}_{3}, \mathrm{BO}_{3}$, $\mathrm{K}, \mathrm{Pb}, \mathrm{Mn}, \mathrm{Cd}$ and $\mathrm{Cu}$ were the major contaminants in the surface water of Sadar upazila of Jamalpur district, Bangladesh. Finally, the study suggested that the surface water in this area needs to treat to minimize the amount of contaminants before use for irrigation.
\end{abstract}

(C)2018 Agriculture and Environmental Science Academy

Citation of this article: Akter, A., Zakir, H.M., Rahman, A., Yesmeen, R. and Rahman, M.S. (2018). Appraisal of surface water quality for irrigation collected from Sadar upazila of Jamalpur district, Bangladesh. Archives of Agriculture and Environmental Science, 3(3): 216-225, https://dx.doi.org/10.26832/24566632.2018.030302

\section{INTRODUCTION}

Surface water pollution due to rapid growth of population, urbanization and industrialization, discharge of waste products and effluents are very common in all over the world including Bangladesh. There are two types of pollution - one is point sources (i.e. emissions, effluents and solid discharge from industries, vehicle exhaustion and metals from smelting and mining etc.) and the other is non-point sources (i.e. soluble salts, use of agrochemicals, disposal of industrial and municipal wastes in agricultural land etc.) (Nriagu and Pacyna, 1988; McGrath et al., 2001; Begum et al., 2014; Zakir et al., 2017a). Each source of contamination has negative effects to plants, animals as well as to the environment, which ultimately affect the human health. Waste water irrigation adds significant quantities of different con- taminants including heavy metals to the soil (Zakir et al., 2017b; Al-Zabir et al., 2016). Consumption of cereals and vegetables grown in such contaminated soil can cause serious health hazard to human (Aysha et al., 2017; Zakir et al., 2018; Haque et al., 2018). Irrigation of crops using surface water is a common practice in Bangladesh. But the quality of water is always ignored by the farmers of the country. If low quality water is applied for irrigation, some ions may accumulate in soils as well as crops and deteriorates soil environment ultimately affecting crop production (Ayers and Westcot, 1985). Several studies reported that the common identifiable contaminants in surface water of Bangladesh are $\mathrm{Pb}, \mathrm{Cd}, \mathrm{Cr}, \mathrm{Cu}, \mathrm{As}, \mathrm{Zn}, \mathrm{Mn}, \mathrm{K}, \mathrm{HCO}_{3}, \mathrm{Cl}$ and $\mathrm{SO}_{4}$, which have significant bad effect on irrigation water quality (Zakir et al., 2012; 2013; 2015; 2016; Bakali et al., 2014; Akter et al., 2015; Hossain et al., 2015; 2017). So, it becomes a prime need 
to conduct field level investigations before using waters for irrigation practices in both rural and urban areas of Bangladesh. Jamalpur district is famous in Bangladesh for the production of different types of agricultural products. The district has significant numbers of rice mills, brick fields, jute mills, sugar mill and fertilizer industry (Banglabatayon, 2018). Considering the fact stated above, this study was conducted to assess surface water quality collected from the Sadar upazila of Jamalpur district, Bangladesh.

\section{MATERIALS AND METHODS}

\section{Water sampling and processing}

Twenty two (22) surface water samples were randomly collected from the Sadar upazila of Jamalpur district, Bangladesh during 15 March to 05 April, 2017 following the sampling techniques as outlined by APHA (2012). The collected water samples were stored in $500 \mathrm{~mL}$ preconditioned clean, high-density polythene bottles for different analysis. Before collection of water samples, bottles were well rinsed following the standard sampling procedures. All water samples were filtered through Whatman No.1 filter paper to remove unwanted solid and suspended material. Then 3-4 drops of nitric acid were added to the samples to avoid any fungal and other pathogenic growth. In laboratory, the samples were kept in a clean, cool and dry place. The chemical analyses of water were done as quickly as possible on arrival at the Laboratory of the Department of Agricultural Chemistry, Bangladesh Agricultural University, Mymensingh-2202, Bangladesh. The locations and detailed information about the sampling sites has been presented in Figure 1 and Table 1, respectively.

\section{Analytical methods}

Filtered surface water samples were analysed for various physicochemical parameters. The $\mathrm{pH}$, electrical conductivity (EC) and total dissolved solids (TDS) were measured within a few hours by using a pH meter (Jenway 3505, UK) and a conductivity meter (SensION ${ }^{\mathrm{TM}}+\mathrm{EC} 5, \mathrm{HACH}$, USA), respectively. Calcium and magnesium was determined titrimetrically using standard

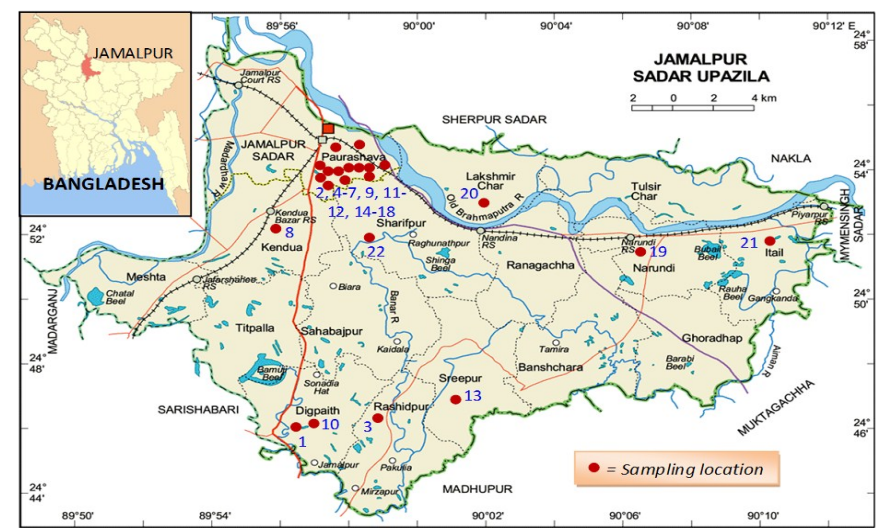

Figure 1. Map showing surface water sampling locations of Sadar upazlia of Jamalpur district, Bangladesh.

$\mathrm{Na}_{2}$-EDTA. Sodium and potassium concentrations were measured by using a flame photometer. Chloride concentration was determined by silver nitrate titration. Carbonate and bicarbonate concentrations were estimated by acid-base titration. Sulphate, borate and phosphate concentrations were measured colorimetrically using a spectrophotometer. Determination of different heavy metals ( $\mathrm{Fe}, \mathrm{Mn}, \mathrm{Cu}, \mathrm{Pb}, \mathrm{Cr}, \mathrm{Cd}$ and $\mathrm{Zn}$ ) in water samples were done by an atomic absorption spectrophotometer (AAS) (SHIMADZU, AA -7000; Japan). Mono element hollow cathode lamp was employed for the determination of each heavy metal of interest.

\section{Evaluation of Irrigation Quality}

To evaluate the suitability of water for irrigation purpose, the following water quality parameters were considered. The ionic concentrations were interpreted and calculated with irrigation indices using the following formulas of different parameters as mentioned below:

i) Sodium adsorption ratio (SAR) $=\mathrm{Na}^{+} / \sqrt{ }\left(\mathrm{Ca}^{2+}+\mathrm{Mg}^{2+}\right) / 2$

li) Soluble sodium percentage (SSP) $=\left\{\left(\mathrm{Na}^{+}+\mathrm{K}^{+}\right) /\left(\mathrm{Ca}^{2+}+\mathrm{Mg}^{2+}+\right.\right.$ $\left.\left.\mathrm{Na}^{+}+\mathrm{K}^{+}\right)\right\} \times 100$

iii) Residual sodium carbonate $(\mathrm{RSC})=\left(\mathrm{CO}_{3}{ }^{2-}+\mathrm{HCO}_{3}{ }^{-}\right)-\left(\mathrm{Ca}^{2+}+\right.$ $\mathrm{Mg}^{2+}$ )

iv) Hardness $\left(\mathrm{H}_{\mathrm{T}}\right)=2.5 \times \mathrm{Ca}^{2+}+4.1 \times \mathrm{Mg}^{2+}$

Where, all ionic concentrations were expressed as meq $\mathrm{L}^{-1}$ but in case of hardness, cationic concentrations were expressed as $\mathrm{mg} \mathrm{L}^{-1}$.

Table 1. Detailed information of water sampling sites of Sadar upazila of Jamalpur district, Bangladesh.

\begin{tabular}{|c|c|c|}
\hline Sample No. & Sampling location & Water sources \\
\hline 1. & Dighuli Primary School ( no. 13) & Pond \\
\hline 2. & Tarif auto flour mill, BSCIC Industrial area, BSCIC & Drain \\
\hline 3. & Rashidpur union & Pond \\
\hline 4. & Rokeya chemical industries (RCI), BSCIC & Drain \\
\hline 5. & Ayesa Abed Foundation, Blockprint unit, BSCIC & Drain \\
\hline 6. & General hospital, Jamalpur & Drain \\
\hline 7. & Dighirper, Chondra & Dighi (big pond) \\
\hline 8. & Kendua bazar, Kendua union & Pond \\
\hline 9. & Rana rice mill, Police line & Drain \\
\hline 10. & National auto rice mill, Sontia bazar, Digpaith & Drain \\
\hline 11. & Paurosova DC office & Drain \\
\hline 12. & Map paper house, Police line & Drain \\
\hline 13. & Kumaria canal, Govindopur, Sreepur union & Canal \\
\hline 14. & Govt. Ashekh Mahmud College & Pond \\
\hline 15. & Alberuni auto rice mill, BSCIC & Drain \\
\hline 16. & $\mathrm{BSCIC}$ area & Pond \\
\hline 17. & Solver Agrofarma, BSCIC & Drain \\
\hline 18. & BDR camp & Drain \\
\hline 19. & Narundi railway station, Narundi union & Pond \\
\hline 20. & Laksmirchar union & River \\
\hline 21. & Jagoroni canal, Piarpur, Itail union & Canal \\
\hline 22. & Godasimla, Sharifpur union & Pond \\
\hline
\end{tabular}




\section{RESULTS AND DISCUSSION}

\section{Quality on the basis of $\mathrm{pH}, \mathrm{EC}$ and TDS}

The $\mathrm{pH}$ value of all water samples were within the range of 4.40 to 7.42 with the mean value of 6.46 (Table 2). According to proposed Bangladesh Standards and Bangladesh Environment Conservation Rule (ECR) the acceptable range of $\mathrm{pH}$ for irrigation water is 6.50 to 8.50 (DoE, 2005; ECR, 1997). Ayers and Westcot (1985) reported the acceptable $\mathrm{pH}$ range for irrigation water is from 6.5 to 8.4 . The measured $\mathrm{pH}$ of 8 water samples had lower $\mathrm{pH}(<6.5)$ than the acceptable range. Due to this reason, those 8 surface water samples were rated as unsuitable for irrigation because these water might be harmful for successful crop production. Electrical conductivity $(E C)$ values of surface water samples varied from 65.10 to $2470.00 \mu \mathrm{sm}^{-1}$ with the mean value of $493.26 \mu \mathrm{sm}^{-1}$ (Table 2). According to Richards (1968), 9 water samples were rated in the category $\mathrm{C} 1$ (EC= $\left.<250 \mu \mathrm{S} \mathrm{cm}^{-1}\right)$; 8 samples were in the class C2 $(E C=250-750 \mu \mathrm{S}$ $\left.\mathrm{cm}^{-1}\right) ; 4$ samples were in the category $\mathrm{C} 3(\mathrm{EC}=750-2250 \mu \mathrm{S} \mathrm{cm}$ $\left.{ }^{1}\right)$ and only 1 sample was in the category C4 (EC > 2250 $\mu \mathrm{S} \mathrm{cm}^{-1}$ ) indicating low to very high salinity classes. Medium salinity class water might be applied with moderate level of permeability and leaching. But higher EC value reflected the higher amount of salt concentration which affected irrigation water quality related to salinity hazard (Agarwal et al., 1982). The maximum and minimum value of measured total dissolved solids (TDS) of collected water samples in the investigated area were 1379.0 and $44.2 \mathrm{mg} \mathrm{L}^{-1}$, respectively, and the mean value of TDS was 287.82 $\mathrm{mg} \mathrm{L}^{-1}$ (Table 2). A sufficient quality of bicarbonate, sulphate and chloride of $\mathrm{Ca}, \mathrm{Mg}$ and $\mathrm{Na}$ caused high TDS values (Karanth, 1994). FAO standard range of TDS value for irrigation practices is 450 to $2000 \mathrm{mg} \mathrm{L}^{-1}$ (Ayers and Westcot, 1985). Classification based on TDS as reported by Freeze and Cherry (1979), 21 water samples under investigation contained less than $1000 \mathrm{mg} \mathrm{L}^{-1}$ TDS and classified as fresh water in quality. These waters would not affect the osmotic pressure of soil solution and cell sap of the plants when applied to soil system as irrigation water. The results on TDS in water quality corroborated the findings of Rahman et al. (2012).

\section{Quality on the basis of major cationic constituents}

Water samples collected from Jamalpur Sadar upazila contained Ca within the range of 1.00 to $6.40 \mathrm{me} \mathrm{L}^{-1}$ with the average value of $2.17 \mathrm{me} \mathrm{L}^{-1}$ (Table 2), and it contributed $36 \%$ to the total cationic mass balance (Figure $2 \mathrm{~b}$ ). The contribution of $\mathrm{Ca}$ content in water was largely dependent on the solubility of $\mathrm{CaCO}_{3}$, $\mathrm{CaSO}_{4}$ and rarely on $\mathrm{CaCl}_{2}$ (Karanth, 1994). Irrigation water containing less than 20 me $\mathrm{L}^{-1} \mathrm{Ca}$ was suitable for irrigating crops (Ayers and Westcot, 1985). Considering this value as standard, all surface water samples could safely be used for irrigation, which will not affect soil properties. The concentration of $\mathrm{Mg}$ in water samples varied from trace to $3.81 \mathrm{me} \mathrm{L}^{-1}$ with the mean value of $1.08 \mathrm{me} \mathrm{L}^{-1}$ (Table 2 ), and it contributed $18 \%$ to the total cationic mass balance (Figure $2 \mathrm{~b}$ ). According to Ayers and Westcot (1985), irrigation water containing less than
5.0 me $\mathrm{L}^{-1} \mathrm{Mg}$ is suitable for irrigating crops and soils. In the study area, $\mathrm{Mg}$ content in all samples were below this range and therefore they are suitable for irrigation. The minimum and maximum potassium content in surface water samples was 0.01 and $17.50 \mathrm{me} \mathrm{L}^{-1}$, respectively. The mean value was $1.57 \mathrm{me} \mathrm{L}^{-1}$ and it contributed $26 \%$ to the total cationic mass balance (Figure 2b). According to Ayers and Westcot (1985), the recommended value of $\mathrm{K}$ in irrigation water is $2.0 \mathrm{mg} \mathrm{L}^{-1}\left(0.05 \mathrm{me} \mathrm{L}^{-1}\right)$. Considering this value as standard, 14 samples of water collected from Jamalpur Sadar upazila of Jamalpur district could be problematic for long-term irrigation. The content of $\mathrm{Na}$ in the water samples was within the range of 0.08 to $3.12 \mathrm{me} \mathrm{L}^{-1}$ with the mean value of $1.17 \mathrm{me} \mathrm{L}^{-1}$ (Table 2), and it contributed $20 \%$ to the total cationic mass balance (Figure 2b). Water generally contained less than $40 \mathrm{me} \mathrm{L}^{-1} \mathrm{Na}$ (Ayers and Westcot, 1985) is suitable for irrigation. The recorded content of $\mathrm{Na}$ in all water samples under investigation area was far below this acceptable limit. Considering the content of this ion, all surface water samples of the study area could safely be used for long-term irrigation without any harmful effect on soils and crops.

\section{Quality on the basis of anionic constituents}

The concentration of $\mathrm{HCO}_{3}$ in surface water samples collected from the Sadar upazila of Jamalpur district ranged from 0.40 to 17.20 me L $^{-1}$ with the mean value of 3.80 me L $^{-1}$ (Table 3 ) and it contributed the highest (82\%) to the total anionic mass balance (Figure 2a). According to Ayers and Westcot (1985), the recommended maximum concentration of $\mathrm{HCO}_{3}$ for irrigation water used continuously on soil is $1.50 \mathrm{me} \mathrm{L}^{-1}$. As per this standard, $\mathrm{HCO}_{3}$ status in 18 water samples were exceeded the limit, thus hazardous for irrigating crops and soils. Bicarbonates are derived mainly from the soil zone $\mathrm{CO}_{2}$ and dissolution of carbonates and reaction of silicates with carbonic acid (Singh et al., 2009) although the carbonate content in the surface water samples was trace (Table 3). Water sample collected from the study area contained $\mathrm{Cl}$ ranging from 0.23 to $5.81 \mathrm{me} \mathrm{L}^{-1}$ with the mean value of $1.20 \mathrm{me} \mathrm{L}^{-1}$ (Table 3 ) and it contributed $15 \%$ to the total anionic mass balance (Figure 2a). According to Bangladesh Standards, the maximum acceptable limit of chloride for irrigation water is $600 \mathrm{mg} \mathrm{L}^{-1}$ (DoE, 2005). The maximum recommended limit of $\mathrm{Cl}$ for irrigation water is $4.0 \mathrm{me} \mathrm{L}^{-1}$ (Ayers and Westcot, 1985). Considering these limits as standard, $\mathrm{Cl}$ content in all water samples was found in suitable category for irrigation except sample no. 15 which contained $5.81 \mathrm{me} \mathrm{L}^{-1} \mathrm{Cl}$. High concentration of chloride is considered to be the indicator of pollution by high organic wastes of animal or industrial origin (Selvakumar et al., 2017). Most of the chloride in water was present as sodium chloride $(\mathrm{NaCl})$ but chloride content may exceed sodium due to the base exchange phenomena (Karanth, 1994). Water sample collected from the Sadar upazila of Jamalpur district contained $\mathrm{PO}_{4}$ ranging from 0.08 to $4.40 \mathrm{mg} \mathrm{L}^{-1}$ and the mean value was 0.61 (Table 3). Accoding to Ayers and Westcot (1985), the maximum acceptable limit of $\mathrm{PO}_{4}$ in water used for irrigation is $2.00 \mathrm{mg} \mathrm{L}^{-1}$. On the basis of this limit, all water samples under investigation area were not problematic for 
Table 2. pH, EC, TDS and major cationic constituents in surface water samples of Sadar upazila of Jamalpur district, Bangladesh.

\begin{tabular}{|c|c|c|c|c|c|c|c|}
\hline Sample No. & $\mathrm{pH}$ & $\mathrm{EC}\left(\mu \mathrm{s} \mathrm{cm}^{-1}\right)$ & $\operatorname{TDS}\left(\mathrm{mg} \mathrm{L}^{-1}\right)$ & $\mathrm{Ca}\left(\mathrm{me} \mathrm{L}^{-1}\right)$ & $\mathrm{Mg}\left(\mathrm{me} \mathrm{L}^{-1}\right)$ & $\mathrm{K}\left(\mathrm{me} \mathrm{L}^{-1}\right)$ & $\mathrm{Na}\left(\mathrm{me} \mathrm{L}^{-1}\right)$ \\
\hline 1. & 7.03 & 65.10 & 44.20 & 1.80 & 1.00 & 0.01 & 0.08 \\
\hline 2. & 5.47 & 474.00 & 274.00 & 2.00 & 1.20 & 0.43 & 0.98 \\
\hline 3. & 6.15 & 121.50 & 78.20 & 1.40 & 1.00 & 0.12 & 0.35 \\
\hline 4. & 6.30 & 208.60 & 132.80 & 1.00 & 2.00 & 0.04 & 1.24 \\
\hline 5. & 6.50 & 195.30 & 123.80 & 1.80 & 0.40 & 0.04 & 0.91 \\
\hline 6. & 6.73 & 847.00 & 466.00 & 3.40 & 0.00 & 0.35 & 3.12 \\
\hline 7. & 6.78 & 257.00 & 171.00 & 2.20 & 1.60 & 0.18 & 0.84 \\
\hline 8. & 6.81 & 196.40 & 118.80 & 2.20 & 0.40 & 0.26 & 0.27 \\
\hline 9. & 5.64 & 1036.00 & 572.00 & 1.00 & 1.80 & 6.88 & 0.79 \\
\hline 10. & 4.91 & 1062.00 & 623.00 & 1.00 & 1.60 & 7.49 & 1.29 \\
\hline 11. & 6.75 & 951.00 & 517.00 & 2.40 & 1.40 & 0.04 & 3.00 \\
\hline 12. & 6.65 & 644.00 & 363.00 & 6.40 & 1.00 & 0.02 & 1.74 \\
\hline 13. & 7.02 & 121.20 & 78.80 & 1.60 & 0.20 & 0.05 & 0.89 \\
\hline 14. & 6.86 & 321.00 & 189.00 & 2.60 & 0.80 & 0.03 & 1.12 \\
\hline 15. & 4.40 & 2470.00 & 1379.00 & 2.60 & 3.81 & 17.50 & 1.77 \\
\hline 16. & 5.83 & 121.10 & 116.20 & 1.40 & 0.40 & 0.34 & 1.22 \\
\hline 17. & 6.12 & 211.50 & 128.20 & 1.60 & 1.00 & 0.06 & 1.01 \\
\hline 18. & 6.98 & 258.00 & 150.10 & 2.20 & 0.00 & 0.17 & 1.46 \\
\hline 19. & 7.42 & 512.00 & 276.00 & 2.40 & 1.40 & 0.20 & 2.05 \\
\hline 20. & 7.41 & 348.00 & 181.00 & 2.80 & 1.40 & 0.07 & 0.35 \\
\hline 21. & 7.29 & 87.00 & 162.00 & 1.20 & 0.20 & 0.05 & 0.56 \\
\hline 22. & 6.99 & 344.00 & 188.00 & 2.80 & 1.20 & 0.21 & 0.75 \\
\hline Max. & 7.42 & 2470.00 & 1379.00 & 6.40 & 3.81 & 17.50 & 3.12 \\
\hline Min. & 4.40 & 65.10 & 44.20 & 1.00 & 0.00 & 0.01 & 0.08 \\
\hline Mean & 6.46 & 493.26 & 287.82 & 2.17 & 1.08 & 1.57 & 1.17 \\
\hline SD & 0.79 & 541.98 & 295.61 & 1.15 & 0.85 & 4.12 & 0.79 \\
\hline
\end{tabular}

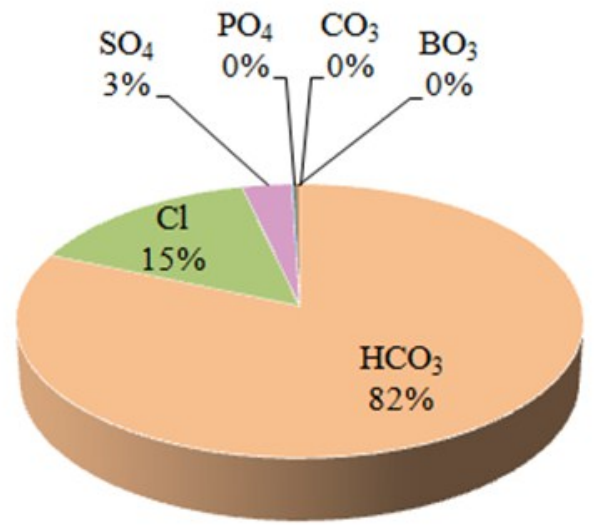

a

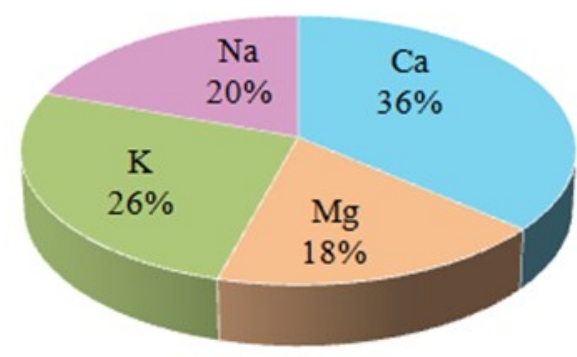

b

Figure 2. Contribution of individual major ions towards the total anionic (a) and cationic (b) mass balance in waters collected from Sadar upazila of Jamalpur districts, Bangladesh.

irrigation except sample no. 16, which contained $4.40 \mathrm{mg} \mathrm{L}^{-1}$ phosphate. The minimum and maximum sulphate $\left(\mathrm{SO}_{4}\right)$ content in water samples were 1.42 and $66.51 \mathrm{mg} \mathrm{L}^{-1}$, respectively with the mean value of $9.03 \mathrm{mg} \mathrm{L}^{-1}$ (Table 3 ) and it contributed $3 \%$ to the total anionic mass balance (Figure $2 a$ ). On a global basis, one third of the $\mathrm{SO}_{4}$ in aquatic systems derived from rock weathering (include two major forms of sulphur sedimentary rocks, pyrite and gypsum), about $60 \%$ from fossil fuel combustion and minor amounts from volcanism (5\%) and cycling salts (2\%) (Berner and Berner, 1987; Singh et al., 2010). According to Ayers and Westcot (1985), the acceptable limit of $\mathrm{SO}_{4}$ in irrigation water is less than $20 \mathrm{mg} \mathrm{L}^{-1}$. As per this limit, 20 water samples were found suitable for irrigating soils and crops, but the rest 2 samples (ID \# 13 and 15) were unsuitable i.e. problematic for irrigating soils and crops in respect of $\mathrm{SO}_{4}$ content in the study area. If the water has boron concentration $<1.0$ then the water is excellent for irrigation purposes, if its values fall in between 1.0-2.0 then the water is good for irrigation, 2.0-3.0 is permissible, 3.0-3.75 is doubtful and $>3.75$ is unsuitable for irrigating tolerant crops as reported by Wilcox (1955). The concentration of borate $\left(\mathrm{BO}_{3}\right)$ in water samples varied from 0.21 to $2.68 \mathrm{mg} \mathrm{L}^{-1}$ with the mean value of 0.72 $\mathrm{mg} \mathrm{L}^{-1}$ (Table 3). According to Ayers and Westcot (1985), the acceptable limit of $\mathrm{BO}_{3}$ in irrigation water is less than 0.75 $\mathrm{mg} \mathrm{L}^{-1}$. As per this limit, out of 22 water samples, 16 samples were not troublesome for irrigating soils and crops but the rest 6 samples were rated as problematic for irrigating soils and crops. 
Table 3. Anionic constituents in surface water samples of Sadar upazila of Jamalpur district, Bangladesh.

\begin{tabular}{|c|c|c|c|c|c|c|}
\hline Sample No. & $\mathrm{CO}_{3}\left(\mathrm{me} \mathrm{L}^{-1}\right)$ & $\mathrm{HCO}_{3}\left(\mathrm{me} \mathrm{L}^{-1}\right)$ & $\mathrm{Cl}\left(\mathrm{me} \mathrm{L}^{-1}\right)$ & $\mathrm{SO}_{4}\left(\mathrm{mg} \mathrm{L}^{-1}\right)$ & $\mathrm{PO}_{4}\left(\mathrm{mg} \mathrm{L}^{-1}\right)$ & $\mathrm{BO}_{3}\left(\mathrm{mg} \mathrm{L}^{-1}\right)$ \\
\hline 1. & Trace & 1.20 & 0.23 & 3.07 & 0.09 & 0.37 \\
\hline 2. & Trace & 4.40 & 0.73 & 2.12 & 0.16 & 0.47 \\
\hline 3. & Trace & 1.60 & 0.51 & 3.07 & 0.15 & 0.26 \\
\hline 4. & Trace & 2.40 & 0.73 & 6.84 & 0.29 & 0.21 \\
\hline 5. & Trace & 2.00 & 0.34 & 2.36 & 0.09 & 0.63 \\
\hline 6. & Trace & 2.40 & 2.37 & 11.56 & 0.26 & 0.32 \\
\hline 7. & Trace & 3.60 & 0.39 & 4.48 & 0.33 & 0.42 \\
\hline 8. & Trace & 1.60 & 0.45 & 3.30 & 0.64 & 0.42 \\
\hline 9. & Trace & 7.60 & 2.59 & 7.08 & 0.42 & 0.95 \\
\hline 10. & Trace & 7.20 & 3.38 & 3.77 & 1.23 & 1.21 \\
\hline 11. & Trace & 2.80 & 2.24 & 4.01 & 0.97 & 0.53 \\
\hline 12. & Trace & 8.40 & 0.34 & 4.25 & 1.08 & 0.32 \\
\hline 13. & Trace & 0.40 & 0.79 & 27.12 & 0.38 & 2.26 \\
\hline 14. & Trace & 3.20 & 0.85 & 1.42 & 0.13 & 0.79 \\
\hline 15. & Trace & 17.20 & 5.81 & 66.51 & 0.08 & 2.68 \\
\hline 16. & Trace & 0.40 & 0.85 & 7.31 & 4.40 & 0.58 \\
\hline 17. & Trace & 2.80 & 0.34 & 8.02 & 0.60 & 0.53 \\
\hline 18. & Trace & 2.40 & 0.51 & 4.25 & 0.18 & 0.84 \\
\hline 19. & Trace & 4.00 & 1.41 & 6.37 & 1.30 & 0.47 \\
\hline 20. & Trace & 4.00 & 0.23 & 3.54 & 0.22 & 0.53 \\
\hline 21. & Trace & 1.20 & 0.45 & 3.07 & 0.13 & 0.47 \\
\hline 22. & Trace & 2.80 & 0.96 & 15.09 & 0.23 & 0.53 \\
\hline Max. & - & 17.20 & 5.81 & 66.51 & 4.40 & 2.68 \\
\hline Min. & - & 0.40 & 0.23 & 1.42 & 0.08 & 0.21 \\
\hline Mean & - & 3.80 & 1.20 & 9.03 & 0.61 & 0.72 \\
\hline SD & - & 3.69 & 1.35 & 14.03 & 0.93 & 0.62 \\
\hline
\end{tabular}

Table 4. Heavy metal constituents in surface water samples of Sadar upazila of Jamalpur district, Bangladesh.

\begin{tabular}{|c|c|c|c|c|c|c|c|}
\hline Sample No. & $\mathrm{Fe}\left(\mathrm{mg} \mathrm{L}^{-1}\right)$ & $\mathrm{Cd}\left(\mathrm{mg} \mathrm{L}^{-1}\right)$ & $M n\left(\mathrm{mg} \mathrm{L}^{-1}\right)$ & $\mathrm{Cu}\left(\mathrm{mg} \mathrm{L}^{-1}\right)$ & $\mathrm{Zn}\left(\mathrm{mg} \mathrm{L}^{-1}\right)$ & $\mathrm{Pb}\left(\mathrm{mg} \mathrm{L}^{-1}\right)$ & $\mathrm{Cr}\left(\mathrm{mg} \mathrm{L}^{-1}\right)$ \\
\hline 1. & 0.005 & 0.021 & 0.012 & 0.005 & 0.008 & 0.063 & 0.002 \\
\hline 2. & 0.005 & 0.011 & 0.652 & 0.006 & 0.015 & 0.037 & 0.007 \\
\hline 3. & 0.006 & 0.008 & 0.019 & 0.005 & 0.016 & 0.012 & 0.005 \\
\hline 4. & 0.008 & 0.022 & 0.303 & 0.005 & 0.073 & 0.017 & 0.006 \\
\hline 5. & 0.103 & 0.016 & 0.340 & 0.495 & 0.181 & 0.040 & 0.008 \\
\hline 6. & 1.606 & 0.022 & 0.419 & 0.005 & 0.046 & 0.013 & 0.012 \\
\hline 7. & 0.003 & 0.004 & 0.213 & 0.012 & 0.002 & 0.015 & 0.003 \\
\hline 8. & 0.159 & 0.015 & 0.018 & 0.015 & 0.011 & 0.017 & 0.001 \\
\hline 9. & 0.645 & 0.013 & 6.090 & 0.027 & 0.037 & 0.030 & 0.008 \\
\hline 10. & 1.390 & 0.008 & 9.843 & 0.037 & 0.096 & 0.011 & 0.003 \\
\hline 11. & 0.006 & 0.009 & 0.567 & 0.026 & 0.003 & 0.014 & 0.007 \\
\hline 12. & 0.008 & 0.012 & 0.398 & 0.007 & 0.012 & 0.046 & 0.008 \\
\hline 13. & 0.147 & 0.005 & 0.334 & 0.204 & 0.089 & 0.012 & 0.008 \\
\hline 14. & 0.004 & 0.006 & 0.021 & 0.315 & 0.014 & 0.017 & 0.004 \\
\hline 15. & 4.605 & 0.006 & 15.274 & 0.082 & 0.309 & 0.013 & 0.005 \\
\hline 16. & 0.006 & 0.012 & 0.019 & 0.012 & 0.012 & 0.017 & 0.006 \\
\hline 17. & 0.004 & 0.002 & 0.018 & 0.003 & 0.016 & 0.022 & 0.008 \\
\hline 18. & 0.008 & 0.011 & 0.015 & 0.008 & 0.012 & 0.015 & 0.005 \\
\hline 19. & 0.009 & 0.005 & 0.239 & 0.017 & 0.005 & 0.018 & 0.006 \\
\hline 20. & 0.004 & 0.008 & 0.015 & 0.011 & 0.009 & 0.021 & 0.005 \\
\hline 21. & 0.005 & 0.001 & 0.013 & 0.011 & 0.003 & 0.015 & 0.008 \\
\hline 22. & 0.518 & 0.005 & 2.946 & 0.003 & 0.016 & 0.017 & 0.008 \\
\hline Max. & 4.605 & 0.022 & 15.274 & 0.495 & 0.309 & 0.063 & 0.012 \\
\hline Min. & 0.003 & 0.001 & 0.012 & 0.003 & 0.002 & 0.011 & 0.001 \\
\hline Mean & 0.421 & 0.010 & 1.717 & 0.060 & 0.045 & 0.022 & 0.006 \\
\hline SD & 1.037 & 0.006 & 3.858 & 0.123 & 0.073 & 0.013 & 0.003 \\
\hline
\end{tabular}


Quality on the basis of heavy metal content

All the surface water samples collected from Jamalpur Sadar upazila under the district of Jamalpur having a little amount of Fe. The Fe concentration in the water samples was within the range of 0.003 to $4.605 \mathrm{mg} \mathrm{L}^{-1}$ with the average value of 0.421 $\mathrm{mg} \mathrm{L}^{-1}$ (Table 4). Ayers and Westcot (1985) reported the maximum acceptable limit of $\mathrm{Fe}$ concentration for irrigation water is $5.00 \mathrm{mg} \mathrm{L}^{-1}$. The Fe concentrations of all samples were below the acceptable limit $\left(5.00 \mathrm{mg} \mathrm{L}^{-1}\right)$ and could be used safely for long term irrigation without any detrimental effect on soil. The amount of $\mathrm{Cd}$ in water samples was varied from 0.001 to 0.022 $\mathrm{mg} \mathrm{L}^{-1}$ with the mean value of $0.01 \mathrm{mg} \mathrm{L}^{-1}$ (Table 4). Water having less than $0.01 \mathrm{mg} \mathrm{L}^{-1} \mathrm{Cd}$ is safe for irrigation as reported by Ayers and Westcot (1985). The detected values of $\mathrm{Cd}$ in 12 water samples under investigation were below this recommended limit, but the rest 10 water samples exceeded the standard value thus these samples of the study area could be problematic for long-term irrigation with detrimental effect on soils and crops. Manganese concentration in water samples varied significantly among the sampling locations and the range was 0.012 to $15.274 \mathrm{mg} \mathrm{L}^{-1}$ with an average value of $1.717 \mathrm{mg} \mathrm{L}^{-1}$ (Table 4). According to Ayers and Westcot (1985), the permissible limit of $\mathrm{Mn}$ in water used for irrigation is $<0.20 \mathrm{mg} \mathrm{L}^{-1}$. Considering this limit, 8 water samples could be safely used for irrigation, but the rest 14 water samples were rated as unsuitable for irrigation and they could exert problematic effect on soil and crops grown in the study area.

The concentration of $\mathrm{Cu}$ in the water samples was within the range of 0.003 to $0.495 \mathrm{mg} \mathrm{L}^{-1}$ with the average value of 0.06 $\mathrm{mg} \mathrm{L}^{-1}$ (Table 4). According to Ayers and Westcot (1985), water having less than $0.20 \mathrm{mg} \mathrm{L}^{-1} \mathrm{Cu}$ is safe for irrigation. Similarly, the National Academy of Science has recommended that for continuous use irrigation effluent water should not contain more than $0.20 \mathrm{mg} \mathrm{L}^{-1} \mathrm{Cu}$ (Gibeault and Cockerham, 1985). The recorded amount of $\mathrm{Cu}$ in 19 water samples under investigation was below this limit and the rest 3 samples contained higher amount of $\mathrm{Cu}$ than the standard limit. So, 19 samples of the study area could be used safely for long-term irrigation without any harmful effect on soil and crops. The amount of $\mathrm{Zn}$ in collected water samples was detected within the range of 0.002 to $0.309 \mathrm{mg} \mathrm{L}^{-1}$ with the mean value of $0.045 \mathrm{mg} \mathrm{L}^{-1}$ (Table 4). The maximum permissible limit of $\mathrm{Zn}$ in water used for irrigation is $2.0 \mathrm{mg} \mathrm{L}^{-1}$ (Ayers and Westcot, 1985). Considering this limit, all water samples could be safely used for irrigation purpose.

The detected concentration of $\mathrm{Pb}$ in collected water samples was varied from 0.011 to $0.063 \mathrm{mg} \mathrm{L}^{-1}$ with the mean value of $0.022 \mathrm{mg} \mathrm{L}^{-1}$ (Table 4). According to ISI (De, 2005), the standard of $\mathrm{Pb}$ for domestic water supplies is $<0.01 \mathrm{mg} \mathrm{L}^{-1}$. Similarly, according to Proposed Bangladesh Standards, the maximum $\mathrm{Pb}$ content for irrigation water is also $0.01 \mathrm{mg} \mathrm{L}^{-1}$ (DoE, 2005). Considering this limit as standard, $\mathrm{Pb}$ concentrations in all surface water samples collected from the study area were found in unsuitable category for irrigation. The content of $\mathrm{Cr}$ in water samples was within the range of 0.001 to $0.012 \mathrm{mg} \mathrm{L}^{-1}$ with the mean value of $0.006 \mathrm{mg} \mathrm{L}^{-1}$ (Table 4). According to Ayers and Westcot (1985) water having less than $0.20 \mathrm{mg} \mathrm{L}^{-1} \mathrm{Cr}$ is safe for irrigation. The detected value of $\mathrm{Cr}$ in all collected water samples under investigation area was below this recommended limit. Considering this value as standard, all samples of the study area could be used safely for long-term irrigation without any detrimental effect on soils and crops.

Table 5. Irrigation quality and suitability of collected surface water samples of Sadar upazila of Jamalpur district, Bangladesh.

\begin{tabular}{|c|c|c|c|c|c|c|c|c|}
\hline \multirow{2}{*}{ Sample No. } & \multirow{2}{*}{ SAR } & \multirow{2}{*}{ SSP } & \multirow{2}{*}{ RSC } & \multirow{2}{*}{$\mathrm{H}_{\mathrm{T}}$} & \multicolumn{4}{|c|}{ Surface water class based on } \\
\hline & & & & & $\mathrm{SAR}^{1}$ & $\mathrm{SSP}^{2}$ & $\mathrm{RSC}^{3}$ & $\mathrm{H}_{\mathrm{T}}{ }^{4}$ \\
\hline 3 & 0.06 & 2.82 & -1.60 & 140.10 & Excellent & Excellent & Suitable & Medium hard \\
\hline 5 & 0.77 & 30.57 & 1.20 & 160.10 & Excellent & Good & Suitable & Hard \\
\hline 6 & 0.32 & 16.39 & -0.80 & 120.06 & Excellent & Excellent & Suitable & Medium hard \\
\hline 7 & 1.01 & 29.81 & -0.60 & 149.94 & Excellent & Good & Suitable & Medium hard \\
\hline 8 & 0.87 & 30.03 & -0.20 & 110.15 & Excellent & Good & Suitable & Medium hard \\
\hline 9 & 2.40 & 50.57 & -1.00 & 170.34 & Excellent & Permissible & Suitable & Hard \\
\hline 10 & 0.61 & 21.12 & -0.20 & 190.09 & Excellent & Good & Suitable & Hard \\
\hline 11 & 0.23 & 16.89 & -1.00 & 130.19 & Excellent & Excellent & Suitable & Medium hard \\
\hline 12 & 0.66 & 73.22 & 4.80 & 139.95 & Excellent & Doubtful & Unsuitable & Medium hard \\
\hline 13 & 1.13 & 77.14 & 4.60 & 129.97 & Excellent & Doubtful & Unsuitable & Medium hard \\
\hline 15 & 2.18 & 44.47 & -1.00 & 190.12 & Excellent & Permissible & Suitable & Hard \\
\hline 12 & 0.90 & 19.24 & 1.00 & 370.56 & Excellent & Excellent & Suitable & Very hard \\
\hline 18 & 0.94 & 34.28 & -1.40 & 90.14 & Excellent & Good & Suitable & Medium hard \\
\hline 20 & 0.86 & 25.26 & -0.20 & 170.19 & Excellent & Good & Suitable & Hard \\
\hline 24 & 0.99 & 75.05 & 10.79 & 319.95 & Excellent & Doubtful & Unsuitable & Very hard \\
\hline 25 & 1.28 & 46.42 & -1.40 & 90.11 & Excellent & Permissible & Suitable & Medium hard \\
\hline 26 & 0.89 & 29.12 & 0.20 & 130.08 & Excellent & Good & Suitable & Medium hard \\
\hline 27 & 1.39 & 42.64 & 0.20 & 110.22 & Excellent & Permissible & Suitable & Medium hard \\
\hline 31 & 1.49 & 37.16 & 0.20 & 190.12 & Excellent & Good & Suitable & Hard \\
\hline 32 & 0.24 & 9.10 & -0.20 & 210.16 & Excellent & Excellent & Suitable & Hard \\
\hline 36 & 0.67 & 30.28 & -0.20 & 70.10 & Excellent & Good & Suitable & Soft \\
\hline 38 & 0.53 & 19.42 & -1.20 & 200.18 & Excellent & Excellent & Suitable & Hard \\
\hline Max. & 2.40 & 77.14 & 10.79 & 370.56 & - & - & - & - \\
\hline Min. & 0.06 & 2.82 & -1.60 & 70.10 & - & - & - & - \\
\hline Mean & 0.93 & 34.59 & 0.55 & 162.86 & - & - & - & - \\
\hline SD & 0.58 & 20.30 & 2.83 & 70.64 & - & - & - & - \\
\hline
\end{tabular}

Legend: ${ }^{1,2,3} \&^{4}=$ Todd (1980); Wilcox (1955); Ghosh et al. (1983) and Sawyer and McCarty (1967), respectively. 


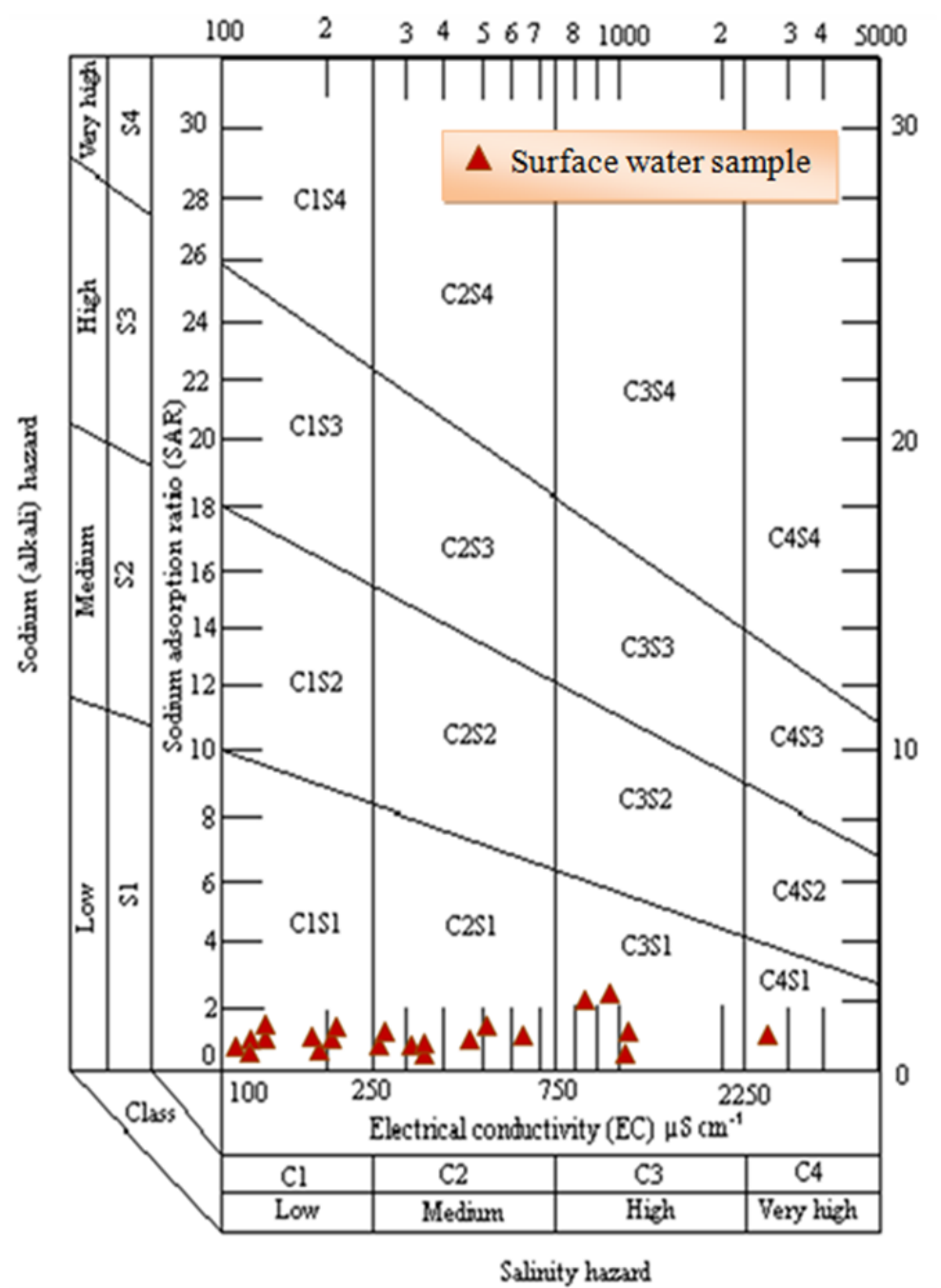

Figure 3. Diagram for classifying surface water used for irrigation (Richards, 1968).

Suitability of water for irrigation usage

The important characteristics or properties of water to be considered for irrigation usage are electrical conductivity, salinity, percent sodium, sodium adsorption ratio and residual sodium carbonate.

\section{Sodium adsorption ratio (SAR)}

The classification on the basis of the salinity or total concentration of soluble salts in irrigation water can be expressed as low $\left(\mathrm{EC}=<250 \mu \mathrm{S} \mathrm{cm}{ }^{-1}\right)$, medium $\left(\mathrm{EC}=250-750 \mu \mathrm{S} \mathrm{cm}{ }^{-1}\right)$, high $(\mathrm{EC}=$ $\left.750-2250 \mu \mathrm{S} \mathrm{cm}^{-1}\right)$ and very high $\left(E C=>2250 \mu \mathrm{S} \mathrm{cm}^{-1}\right)$. In case of high salinity (high EC) in water leads to formation of saline soil, a high sodium concentration changes soil properties and reduce soil permeability, which leads to develop alkaline soil (Singh et al., 2010). The detected sodium adsorption ratio of collected water samples was within the range of 0.06 to 2.40 with the average value of 0.93 (Table 5). When the SAR value of water less than 10 is used for irrigation might not exert any detrimental effect to the crops (Todd, 1980). According to this classification, all water samples were graded as excellent category for irrigation purpose. The present study revealed that a good proportion of $\mathrm{Ca}$ and $\mathrm{Mg}$ existed in all water samples. When data was plotted on the US salinity diagram as described by Richards (1968), in which the EC is taken as salinity hazard and
SAR as alkalinity hazard showed that out of 22 samples, 9 water samples were in the category of $\mathrm{C} 1 \mathrm{~S} 1$; 8 samples were in the category of $\mathrm{C} 2 \mathrm{~S} 1 ; 4$ water samples were in the category of C3S1 and the remaining 1 sample was in the category of C4S1, that indicate low to very high salinity and low alkali hazard (Figure 3). Water having very high salinity hazard cannot be used for irrigation with restricted drainage and it requires special management for salinity control (i.e. good drainage, high leaching and organic matter addition) and plants with good salt tolerance should be selected for such area. Low sodium content water (S1) can be used for irrigation on almost all soils with little danger of the development of harmful levels of exchangeable sodium.

Soluble sodium percentage (SSP)

For classification of irrigation water, electrical conductivity (EC) and sodium concentration are very important parameter. The suitability of water quality for irrigation depends mostly on the Na percentage. Saleh et al. (1999) described that high $\mathrm{Na}$ in irrigation water causes exchange of $\mathrm{Na}$ in water for $\mathrm{Ca}$ and $\mathrm{Mg}$ in soil, which reduces permeability and results soil with poor internal drainage. The salts present in the water, besides affecting the growth of plants directly, also affects soil structure, permeability and aeration, which indirectly affects plant growth (Saleh et al., 1999). The recorded SSP value of all the collected water samples varied from 2.82 to $77.14 \%$ with the 
average value of $34.59 \%$ (Table 5). According to water classification proposed by Wilcox (1955), 6 samples were classified as excellent (SSP < 20\%), 9 samples were rated as good class (SSP $=20-40 \%$ ); 4 samples were rated as permissible class ( $\mathrm{SSP}=41-60 \%)$ and the rest 3 samples were rated as doubtful class ( $\mathrm{SSP}=61-80 \%)$. So, it can be inferred that most of water samples might safely be used for irrigating agricultural crops as regards to SSP.

\section{Residual sodium carbonate (RSC)}

The quantity of bicarbonate and carbonate in excess of alkaline earths also influence the suitability of water for irrigation purposes. When the sum of carbonates and bicarbonates is in excess of calcium and magnesium, precipitation of $\mathrm{Ca}$ and $\mathrm{Mg}$ may occur (Raghunath, 1987). To quantify the effects of carbonate and bicarbonate, RSC has been computed. A high RSC value in water leads to an increase in the adsorption of $\mathrm{Na}$ on soil. Irrigation water having RSC values greater than $5 \mathrm{me} \mathrm{L}^{-1}$ are considered harmful to the growth of plants, while water with RSC value above $2.50 \mathrm{me} \mathrm{L}^{-1}$ are not considered suitable for irrigation. Hence, continued usage of high RSC water will affect the yields of crop (Ghosh et al., 1983). The computed RSC value as obtained from the data generated out of chemical analyses of water samples ranged from -1.60 to $10.79 \mathrm{me} \mathrm{L}^{-1}$ with mean value of 0.55 $\mathrm{me} \mathrm{L}^{-1}$ (Table 5). Among the water samples under test, some samples contained negative value. According to Ghosh et al. (1983), 19 water samples were classified as suitable (RSC $=<1.25 \mathrm{me} \mathrm{L}^{-1}$ ); and the rest 3 samples were categorized as unsuitable class (RSC= $>2.50 \mathrm{me} \mathrm{L}^{-1}$ ). So, most of the water samples might not be problematic for irrigation usage as regards to RSC.

\section{Hardness $\left(\mathrm{H}_{\mathrm{T}}\right)$}

Hardness of water resulted due to the abundance of divalent cations like $\mathrm{Ca}$ and $\mathrm{Mg}$ (Todd, 1980). Hard water is unsuitable for domestic use, as well as hardness of water limits its use for industrial purposes. The calculated hardness $\left(\mathrm{H}_{\mathrm{T}}\right)$ of all collected water samples varied from 70.10 to $370.56 \mathrm{mg} \mathrm{L}^{-1}$ with the mean value of $162.86 \mathrm{mg} \mathrm{L}^{-1}$ (Table 5). Sawyer and McCarty (1967) suggested a classification for irrigation water based on hardness, and according to this classification, among 22 collected water samples 2 were very hard $\left(H_{T}=>300 \mathrm{mg} \mathrm{L}^{-1}\right)$, 8 were hard $\left(H_{T}=150-300\right.$ $\left.\mathrm{mg} \mathrm{L}^{-1}\right), 11$ were moderately hard $\left(\mathrm{H}_{\mathrm{T}}=75-150 \mathrm{mg} \mathrm{L}^{-1}\right)$ and only one was soft in quality $\left(\mathrm{H}_{\mathrm{T}}=0-75 \mathrm{mg} \mathrm{L}^{-1}\right)$.

\section{Conclusion}

The study results revealed that the surface water samples collected from the Sadar upazila of Jamalpur district showed dominance of major cationic constituents in the order of $\mathrm{Ca}>\mathrm{K}>$ $\mathrm{Na}>\mathrm{Mg}$. Among the anions, $\mathrm{HCO}_{3}$ contents contributed the highest (82\%) to the total anionic mass balance and the order of magnitude was $\mathrm{HCO}_{3}>\mathrm{Cl}>\mathrm{SO}_{4}>\mathrm{BO}_{3}>\mathrm{PO}_{4}>\mathrm{CO}_{3}$. Regarding major cations and anions, the study inferred that $\mathrm{K}, \mathrm{HCO}_{3}$ and $\mathrm{BO}_{3}$ are the main contaminants in water, which makes 14,18 and 6 samples unsuitable for irrigation, respectively. In respect of heavy metal contents in surface water, the concentration of $\mathrm{Pb}, \mathrm{Mn}, \mathrm{Cd}$ and Cu were comparatively higher than the standard limits, which makes 22, 14, 10 and 3 samples problematic for long term irrigation in the study area. Classification on the basis of computed SAR values indicates waters into low to very high salinity and low alkali hazard classes. As regards to hardness, out of 22 water samples, 2 were very hard and 8 samples were in hard category. So, the substances/ materials which may cause contamination to the surface water should be avoided through the use of good management agricultural practices, particularly agrochemicals (fertilizers and pesticides) should be used in such a way which maximizes their use by the crops and minimizes losses to the ecosystem. Furthermore, peoples should be aware not to discharge and/ or dispose any chemical substances/ materials without treatment which may ultimately contaminate surface water. The study results concluded that $\mathrm{HCO}_{3}, \mathrm{BO}_{3}, \mathrm{~K}, \mathrm{~Pb}, \mathrm{Mn}, \mathrm{Cd}$ and $\mathrm{Cu}$ were the major contaminants in the surface water of Sadar upazila of Jamalpur district, Bangladesh. Finally, the study suggested that the surface water in this area needs to treat to minimize the amount of contaminants before use for irrigation.

Open Access: This is open access article distributed under the terms of the Creative Commons Attribution License, which permits unrestricted use, distribution, and reproduction in any medium, provided the original author(s) and the source are credited.

\section{REFERENCES}

Agarwal, R.R., Yadav, J.P. and Gupta, R.N. (1982). Saline and Alkali Soils of India. Indian Council of Agricultural Research, New Delhi, India. pp. 223-228.

Akter, A., Mia, M.Y. and Zakir, H.M. (2015). Arsenic contamination in surface and groundwater in major parts of Manikganj district, Bangladesh. Journal of Bangladesh Agricultural University, 13(1): 47-54.

Al-Zabir, A., Zaman, M.W., Zakir, H.M., Uddin, M.N., Biswas, M.J.H. and Al-Asif, A. (2016). Impact of wastewater irrigation on major nutrient status in soil near Bhaluka industrial area of Bangladesh. Asian Journal of Medical and Biological Research, 2(1): 131-137. https://dx.doi.org 10.3329/ ajmbr.v2i1.27578

APHA (American Public Health Association). (2012). Standard Methods for the Examination of Water and Wastewater. $22^{\text {nd }}$ Edition, AWWA and WEF, Washington, USA. pp. 1-30 $\sim 40-175$.

Ayers, R.S. and Westcot, D.W. (1985). Water Quality for Agriculture. FAO Irrigation and Drainage Paper. FAO, Rome. 29(Rev. I): 1-144.

Aysha, M.I.J., Zakir, H.M., Haque, R., Quadir, Q.F., Choudhury, T.R., Quraishi, S.B. and Mollah, M.Z.I. (2017). Health risk assessment for population via consumption of vegetables grown in soils artificially contaminated with arsenic. Archive of Current Research International, 10(3): 1-12, https://dx.doi.org/10.9734/ACRI/2017/37612

Bakali, B., Mia, M.Y. and Zakir, H.M. (2014). Water quality 
evaluation of Tongi area in Bangladesh: an impact of industrialization. Journal of Chemical, Biological and Physical Sciences, 4(2): 1735-1752.

Banglabatayon (2018). The National Web Portal of Bangladesh (www.bangladesh.gov.bd/). District Portal (www.jamalpur.gov.bd/). Accessed on June 20, 2018.

Begum, K., Mohiuddin, K.M., Zakir, H.M., Rahman, M.M. and Hasan, M.N. (2014). Heavy metal pollution and major nutrient elements assessment in the soils of Bogra city in Bangladesh. Canadian Chemical Transactions, 2(3): 316-326. https:// dx. doi. org/ 10.13179/ canchemtrans. 2014.02.03.0088

Berner, E.K. and Berner, R.A. (1987). The Global Water Cycle: Geo-chemistry and Environment. Prentice-Hall, Englewood Cliffs. 387 p.

De, A.K. (2005). Environmental Chemistry. $5^{\text {th }}$ Edition, New Age International Publishers, New Delhi, India, 242 p. and pp. 189-200.

DoE (Department of Environment). (2005). Government of the People's Republic of Bangladesh, Ministry of Environment and Forest, Department of Environment. Dhaka, Bangladesh.

ECR (Environment Conservation Rules). (1997). Government of the People's Republic of Bangladesh, Ministry of Environment and Forest, Department of Environment. Dhaka, Bangladesh. pp. 212-214.

Freeze, A.R. and Cherry, J.A. (1979). Groundwater. Prentice Hall Inc., Englewood Cliffs, New Jersey, USA. pp. 84-387.

Ghosh, A.B., Bajaj, J.C., Hasan, R. and Singh, D. (1983). Soil and Water Testing Methods. A Laboratory Manual. Div. Soil Sci. \& Agric. Chem., IARI, New Delhi, India. pp. 1-48.

Gibeault, V.A. and Cockerham, S.T. (1985). Turfgrass, Water Conservation. ANR Publications, University of California. $155 \mathrm{p}$.

Haque, R., Zakir, H.M., Aysha, M.I.J., Supti Mallick and Rahman, M.S. (2018). Heavy metal uptake pattern and potential human health risk through consumption of tomato grown in industrial contaminated soils. Asian Journal of Advances in Agricultural Research, 5(4): 1-11, https://dx.doi.org/ 10.9734/AJAAR/2018/40169

Hossain, M.A., Zakir, H.M., Kumar, D. and Alam, M.S. (2017). Quality and metallic pollution level in surface waters of an urban industrialized city: a case study of Chittagong city, Bangladesh. Journal of Industrial Safety Engineering, 4(2): 9-18.

Hossain, M.S., Zakir, H.M., Rahman, M.S. and Islam, M.M. (2015). Toxic metallic contamination in wastewater of some industrial areas of Mymensingh town, Bangladesh. Advances in Architecture City and Environment, 1(3): 7-13.

Karanth, K.R. (1994). Ground Water Assessment Development and Management. TATA McGrew-Hill Publishing Company Limited. New Delhi, India. pp. 217-273.

McGrath, S.P., Zhao, F.J. and Lombi, E. (2001). Plant and rhizosphere process involved phytoremediation of metal contaminated soils. Plant and Soil, 232(1/2): 207-214, https://doi.org/10.1023/A:1010358708525

Nriagu, J.O. and Pacyna, J.M. (1988). Quantitative assessment of worldwide contamination of air water and soils by trace metals. Nature, 333(6169): 134-139, https://dx. doi.org/ $10.1038 / 333134 \mathrm{aO}$

Raghunath, H.M. (1987). Ground Water. $2^{\text {nd }}$ Edition, Wiley Eastern Limited. New Delhi, India. 353 p.

Rahman, A.K.M.L., Islam, M., Hossain, M.Z. and Ahsan, M.A. (2012). Study of the seasonal variations in Turag river water quality parameters. African Journal of Pure Applied Chemistry, 6(10): 144-148.

Richards, L.A. (ed.) (1968). Diagnosis and Improvement of Saline and Alkali Soils. USDA and IBH Publishing Co. Ltd. New Delhi, India.pp. 98-99.

Saleh, A., Al-Ruwaih, F. and Shenta, M. (1999). Heavy Metal Contaminations in the Environment. Sabdagussa Press, New York. pp. $1 \& 54$.

Sawyer, C.N. and McCarty, P.K. (1967). Chemistry for Sanitary Engineers. $2^{\text {nd }}$ Edition, McGraw Hill, New York, USA. 518 p.

Selvakumar, S., Ramkumar, K., Chandrasekar, N., Magesh, N.S. and Kaliraj, S. (2017). Groundwater quality and its suitability for drinking and irrigational use in the Southern Tiruchirappalli district, Tamil Nadu, India. Applied Water Science, 7(1): 411 420, https://dx.doi.org/10.1007/s13201-014-0256-9

Singh, A.K., Mondal, G.C., Kumar, S., Singh, T.B., Tewary, B.K. and Sinha, A. (2009). Major ion chemistry, weathering processes and water quality assessment in upper catchment of Damodar river basin, India. Environmental Geology, 54: 745-758.

Singh, A.K., Mahato, M.K., Neogi, B. and Singh, K.K. (2010). Quality assessment of mine water in the Raniganj coalfield area, India. Mine Water Environment, 29: 248-262, https:// dx.doi.org/10.1007/s10230-010-0108-2

Todd, D.K. (1980). Groundwater Hydrology. $2^{\text {nd }}$ Edition, John Wiley and Sons. Inc., New York, USA. pp. 267-315.

Wilcox, L.V. (1955). Classification and use of irrigation water. United States Department of Agriculture Circular No. 969. Washington, USA. p. 19.

Zakir, H.M., Arafat, M.Y. and Islam, M.M. (2017a). Assessment of metallic pollution along with geochemical baseline of soils at Barapukuria open coal mine area in Dinajpur, Bangladesh. Asian Journal of Water, Environment and Pollution, 14 (4): 77-88, https://dx.doi.org/10.3233/AJW-170038

Zakir, H.M., Aysha, M.I.J., Mallick, S., Sharmin, S., Quadir, Q.F. and Hossain, M.A. (2018). Heavy metals and major nutrients accumulation pattern in spinach grown in farm and industrial contaminated soils and health risk assessment. Archives of Agriculture and Environmental Science, 3(1): 95-102, https:// dx. doi.org/ 10.26832/ 24566632.2018. 0301015

Zakir, H.M., Islam, M.M. and Hossain, M.S. (2016). Impact of urbanization and industrialization on irrigation water quality of a canal- a case study of Tongi canal, Bangladesh. Advances in Environmental Research, 5(2): 109-123, https:// dx.doi.org/10.12989/aer.2016.5.2.109

Zakir, H.M., Islam, M.M. and Hossain, M.S. (2017b). Heavy metal contents in sediments of an urban industrialized area- a case study of Tongi canal, Bangladesh. Asian Journal of Water, Environment and Pollution, 14(1): 59-68, https:// dx.doi.org/10.3233/AJW-170007 
Zakir, H.M., Islam, M.M., Arafat, M.Y. and Sharmin, S. (2013). Hydrogeochemistry and quality assessment of waters of an open coal mine area in a developing country: a case study from Barapukuria, Bangladesh. International Journal of Geosciences Research, 1(1): 20-44.

Zakir, H.M., Rahman, M.M., Rahman, A., Ahmed, I. and Hossain, M.A. (2012). Heavy metals and major ionic pollution assessment in waters of midstream of the river Karatoa in Bangladesh. Journal of Environmental Science and Natural Resources, 5(2): 149-160.

Zakir, H.M., Sattar, M.A. and Quadir, Q.F. (2015). Cadmium pollution and irrigation water quality assessment of an urban river: a case study of the Mayur river, Khulna, Bangladesh. Journal of Chemical, Biological and Physical Sciences, 5(2): 21332149. 